\title{
Penjantanan ikan gapi, Poecilia reticulata Peters, 1859 dengan pemberian ekstrak jeroan teripang pasir (Holothuria scabra)
}

\author{
[Masculinization of guppy fish (Poecilia reticulata Peters, 1859) with extract of sea cucumber \\ (Holothuria scabra)]
}

\section{Anugerah Saputra, Astri Wulandari, Ernawati, Muhammad Amri Yusuf, Irvan Eriswandy, Andi Aliah Hidayani ${ }^{\bowtie}$}

Jurusan Perikanan, Fakultas Ilmu Kelautan dan Perikanan, Universitas Hasanuddin, Kampus Tamalanrea,

Jl. Perintis Kemerdekaan Km. 10, Makassar, 90245

Diterima: 29 Juni 2017; Disetujui: 1 Mei 2018

\begin{abstract}
Abstrak
Ikan gapi Poecilia reticulata merupakan salah satu jenis ikan hias air tawar yang banyak digemari karena mudah dipelihara, dan memiliki variasi wama yang indah, terutama jantannya. Salah satu metode untuk menghasilkan ikan gapi jantan adalah dengan metode pembalikan kelamin melalui produksi penjantanan ikan gapi. Penelitian ini bertujuan untuk menentukan dosis hormon perlakuan ekstrak jeroan teripang pasir terhadap proses penjantanan ikan gapi. Penelitian ini menggunakan rancangan acak lengkap dengan perlakuan perendaman induk ikan gapi yang telah dipijahkan ke dalam larutan ekstrak jeroan teripang pasir selama 24 jam dengan dosis berbeda, yaitu $0 \mathrm{mg} \mathrm{L}^{-1}, 10 \mathrm{mg} \mathrm{L}^{-1}, 20 \mathrm{mg} \mathrm{L}^{-1}$, $30 \mathrm{mg} \mathrm{L}^{-1}$ dan $22 \mathrm{mg} \mathrm{L}^{-1}$ (metiltestosteron sebagai kontrol positif). Parameter yang diukur adalah persentase ikan jantan yang dihasilkan. Hasil penelitian menunjukkan bahwa walaupun pengaruh antarperlakuan yang diberikan tidak berbeda nyata, tetapi dapat dikatakan berbeda nyata terhadap perlakuan $0 \mathrm{mg} \mathrm{L}^{-1}$ (kontrol) sehingga diperoleh hasil terbaik untuk penjantanan ikan gapi pada dosis perendaman $30 \mathrm{mg} \mathrm{L}^{-1}$ dan sintasan terbaik pada perlakuan $0 \mathrm{mg} \mathrm{L}^{-1}$ (kontrol). Hasil penelitian ini memberikan informasi bahwa teknologi penjantanan pada induk ikan gapi dapat dilakukan dengan memanfaatkan ekstrak jeroan teripang pasir yang selama ini dianggap sebagai limbah.
\end{abstract}

Kata penting: ikan gapi, metiltestosteron, sintasan, teripang pasir

\begin{abstract}
Guppy fish Poecilia reticulata is one of the most popular freshwater ornamental fish species because it is easy to maintain, and has beautiful variations of color, especially males. One method to produce male guppy is masculinization method. This study aimed to determine the dose of hormone treatment from visceral organ of sea cucumber to the process masculinization of fish guppy. This study used a completely randomized design with the immersion treatment of parent guppy which has been bred into the extract solution of sea cucumber innards for 24 hours with different doses i.e. $0 \mathrm{mg}$ $\mathrm{L}^{-1}, 10 \mathrm{mg} \mathrm{L}^{-1}, 20 \mathrm{mg} \mathrm{L}^{-1}, 30 \mathrm{mg} \mathrm{L}^{-1}$ and $22 \mathrm{mg} \mathrm{L}^{-1}$ (metiltestosterone as positive control). The parameter measured was the percentage of male fish produced. The results showed that although the effect of the treatment was not significantly different, but it can be said to be significantly different to the treatment of $0 \mathrm{mg} \mathrm{L}^{-1}$ (control) to obtain the best result for masculinization of guppy at $30 \mathrm{mg} \mathrm{L}^{-1}$ immersion and the best survival rate on treatment of $0 \mathrm{mg} \mathrm{L}^{-1}$ (control). The results of this study suggest that the masculinization technology on the parent stock can be done using extracts of sea cucumber innards which has been considered as waste.
\end{abstract}

Keywords: guppy fish, methyltestosterone, survival rate, sea cucumber

\section{Pendahuluan}

Ikan gapi (Poecilia reticulata) merupakan salah satu jenis ikan hias air tawar yang banyak dibudidayakan karena mudah dipelihara serta memiliki variasi wama yang indah, terutama pada ikan jantan (Zairin et al. 2002). Penampakan morfologi ikan gapi jantan sangat berbeda dengan betina. Ikan gapi jantan mempunyai warna

$\triangle$ Penulis korespondensi

Alamat surel: aliah.achsan80@gmail.com tubuh yang cemerlang dengan pola wama yang beragam, sedangkan wama tubuh betina umumnya monoton. Selanjutnya Zairin et al. (2002) juga menyatakan bahwa warna tubuh, bentuk sirip ekor dan pola warna tubuh ikan gapi terkait dengan jenis kelamin. Adanya perbedaan dalam penampakan tersebut menyebabkan ikan gapi jantan lebih bernilai ekonomis dibandingkan dengan betina, sehingga budi daya ikan gapi kela- 
min tunggal jantan sangat diminati oleh para pembudidaya ikan (Muslim 2010).

Faktor genetik yang didukung oleh lingkungan sangat menentukan jenis kelamin suatu individu, namun pengarahan kelamin pada ikan dapat dilakukan dengan pemberian hormon steroid (Mardiana 2009), dengan memanfaatkan fase diferensiasi kelamin (Sarida et al. 2011). Tujuan utama teknik pembalikan kelamin ini adalah menghasilkan populasi kelamin tunggal, karena pembudidayaan ikan kelamin tunggal memiliki banyak keuntungan seperti pertumbuhan yang lebih cepat, mencegah pemijahan liar, mendapatkan performa yang menarik serta dapat menunjang genetik ikan melalui teknik pemurnian ras ikan (Zairin 2002). Pembalikan kelamin secara buatan dapat dilakukan karena pada awal perkembangan embrio atau larva belum terjadi diferensiasi kelamin. Diferensiasi kelamin ini sangat erat kaitannya terhadap seluruh aktivitas yang berhubungan dengan keberadaan gonad dimulai dari perpindahan awal sel nutfah, munculnya bagian tepi gonad dan diferensiasi gonad menjadi testis atau ovari (Muslim 2011). Proses diferensiasi kelamin dimulai ketika gonad berkembang baik menjadi spermatogonia maupun oogonia dan semua gonad vertebrata memiliki jaringan yang akan terdiferensiasi menjadi testis atau ovari (Emilda 2015). Proses pengarahan jenis kelamin pada ikan dapat dilakukan dengan memanipulasi suhu lingkungan (Arfah et al. 2005) atau melalui perlakuan hormon pada periode labil (sebelum terjadi diferensiasi kelamin) (Riani et al. 2010).

Hormon yang umum digunakan dalam pembalikan kelamin jantan adalah hormon steroid jenis androgen seperti testosteron atau metiltestosteron (Triajie 2010). Hormon ini berperan dalam memacu pertumbuhan dan pembentukan sifat kelamin jantan. Hormon steroid yang sering digunakan dalam teknik ini adalah $17 \alpha$-metiltestosteron yang merupakan hormon sintetik dengan perubahan molekul pada atom karbon ke-17 diinduksikan gugus metil yang bertujuan lebih lama bereaksi di dalam tubuh (Muslim 2010). Namun, dalam perkembangannya, penggunaan hormon sintetik ini mulai dibatasi karena berpotensi mengganggu sistem endokrin, hipoksia pada manusia, ikan dan hewan lain yang terdedah baik secara langsung maupun tidak langsung (Sarida et al. 2011). Kelemahan lainnya yaitu residunya menjadi bahan pencemar lingkungan (Phelps et al. 2001) dan juga menjadi penyebab kanker pada manusia (Sudrajat \& Sarida 2006), dan dapat mengakibatkan paradoksial menjadi betina, terutama bila waktu pemberian yang terlalu lama (Gemilang et al. 2016). Penggunaan hormon ini secara berlebihan akan menyebabkan ikan menjadi jantan sebelum waktunya sehingga akan menghambat pertumbuhan (Mantau 2005). Pelarangan penggunaan hormon tersebut juga diperkuat dengan adanya Surat Keputusan Menteri Kelautan dan Perikanan KEP.20/MEN/2003 yang mencantumkan bahwa hormon $17 \alpha$-metiltestosteron termasuk dalam obat keras (Akbar \& Hanafie 2013) yang dapat memengaruhi keamanan pangan dan kelestarian lingkungan (Haq et al. 2013). Selain itu peredaran hormon ini terbatas sehingga harga mahal dan sulit diperoleh (Mus$\lim$ 2010). Oleh karena itu, diperlukan alternatif pengganti hormon sintetik tersebut dengan hormon alami dari ekstrak jeroan teripang pasir untuk kegiatan pembalikan kelamin jantan.

Teripang pasir (Holothuria scabra) merupakan salah satu biota laut yang memiliki kandungan protein tinggi, kadar lemak rendah serta dipercaya sebagai afrodisiak karena kandungan steroid yang tinggi (Emilda 2015). Kandungan gizi yang dimiliki teripang antara lain 9 jenis karbohidrat, 59 jenis asam lemak, 19 jenis asam 
amino, 25 komponen vitamin, 10 jenis mineral dan 5 jenis sterol (Triajie 2010). Kandungan asam amino yang tertinggi pada teripang pasir adalah prolin dan asam glutamat yang berfungsi sebagai penghasil senyawa steroid jenis testosteron yang merupakan hormon androgen (Karnila et al. 2011). Salah satu bagian teripang pasir yang memiliki kandungan steroid tertinggi adalah esktrak jeroan teripang pasir, di mana $1 \mathrm{~kg}$ jeroan basah (21,28 g ekstrak kasar) mengandung steroid 6,124 $\mu \mathrm{g} \mathrm{kg}^{-1}$ jenis testosteron (Kustiariyah 2006). Umumnya steroid pada hewan dihasilkan dari organ reproduksi dan organ visceral salah satunya adalah usus yang selama ini tidak termanfaatkan (limbah) yang tidak bernilai ekonomis lagi. Hormon steroid inilah yang pertama kali akan merangsang fenomena reproduksi seperti merangsang diferensiasi gonad, gametogenesis, ovulasi, spermatogenesis, pemijahan dan tingkah laku kawin. Selanjutnya steroid akan merangsang ciri-ciri kelamin eksternal, perubahan morfologi dan fisiologi saat memijah dan produksi feromon (Emilda 2015).

Secara fisiologis, pemberian hormon steroid dapat mengarahkan jenis kelamin ikan terutama jika diberikan sebelum gonad berdiferensiasi (Piferrer 2001). Beberapa faktor yang dapat memengaruhi efektifitas pemberian hormon yaitu metode pemberian hormon, jenis dan dosis hormon, waktu diferensiasi kelamin serta suhu (Yuniarti et al. 2009). Metode pemberian hormon steroid terbaik dalam mengarahkan diferensiasi kelamin adalah melalui oral dan perendaman (Mardiana 2009). Menurut Piferrer (2001) perlakuan dosis hormon sangat terkait dengan lama perlakuan. Terdapat hubungan terbalik antara tingkat dosis dan lama perendaman di mana dosis yang lebih tinggi membutuhkan waktu perendaman yang lebih singkat dan begitupun sebaliknya dengan dosis yang rendah membutuhkan waktu yang lebih lama (Hunter \& Donaldson 1983). Penelitian ini bertujuan untuk menentukan dosis hormon ekstrak jeroan teripang pasir dengan waktu perendaman induk yang sedang bunting selama 24 jam terhadap proses penjantanan ikan gapi.

\section{Bahan dan Metode}

\section{Waktu dan tempat}

Penelitian ini dilaksanakan di Panti Pembenihan, Fakultas Ilmu Kelautan dan Perikanan Universitas Hasanuddin (UNHAS) pada bulan April sampai Juni 2017. Pembuatan ekstrak jeroan teripang pasir dilakukan di Laboratorium Bioteknologi, Fakultas Peternakan, Universitas Hasanuddin.

\section{Rancangan percobaan}

Penelitian ini menggunakan Rancangan Acak Lengkap satu faktor dengan tiga ulangan. Faktor yang diuji adalah perbedaan dosis perendaman lima taraf perlakuan (Yustina et al. 2012) yaitu perlakuan A (0 mg L-1, Kontrol); B (10 mg $\left.\mathrm{L}^{-1}\right)$; C (20 mg L $\left.{ }^{-1}\right) ; \mathrm{D}\left(30 \mathrm{mg} \mathrm{L}^{-1}\right)$, dan E (22 mg $\mathrm{L}^{-1}$, metiltestosteron). Ikan uji yang digunakan adalah induk ikan gapi berumur enam bulan yang dipilih secara acak serta dipijahkan secara alami dalam wadah terkontrol dengan perbandingan jantan dan betina $4: 3$.

\section{Pembuatan ekstrak jeroan teripang pasir dan proses perendaman ikan}

Ekstrak jeroan teripang pasir ini dibuat dengan cara mengeluarkan usus teripang pasir dan diletakkan dalam wadah, kemudian dibekukan dalam freezer (24 jam). Wadah yang berisi jeroan teripang pasir dimasukkan ke dalam freeze dry selama 24 jam pada suhu $-75^{\circ} \mathrm{C}$ dan tekanan -0,1 Mpa. Setelah kering jeroan teripang diblender, lalu diayak dengan saringan halus $(0,42$ 
$\mathrm{mm})$. Ekstrak jeroan teripang pasir siap digunakan untuk proses penjantanan ikan gapi.

Pembuatan larutan perendaman dilakukan dengan cara melarutkan tepung teripang dengan larutan metanol (alkohol 90\%) sebanyak $1 \mathrm{ml}$ dalam masing-masing wadah perendaman yang telah diisi 1 liter air, kemudian diberi aerasi agar ekstrak jeroan teripang pasir larut dalam air. Media perendaman yang digunakan sebanyak 15 buah. Perendaman induk bunting dalam larutan ektrak jeroan teripang pasir dilakukan dengan per-lakuan A, B, C, D dan E selama 24 jam.

Setelah melalui proses perendaman, induk ikan gapi dipelihara masing-masing dalam akuarium ukuran $50 \mathrm{~cm} \times 30 \mathrm{~cm}$ x $25 \mathrm{~cm}$ sebanyak 15 buah. Sebelum digunakan, akuarium untuk pemeliharaan dicuci terlebih dahulu agar bebas dari kotoran, kemudian dibilas dengan air bersih, lalu masing-masing akuarium diisi dengan air bersih sebanyak 2 L yang telah diendapkan selama 24 jam sebelumnya. Selama masa pemeliharaan, induk dan anak gapi yang telah lahir diberi pakan diantaranya berupa pakan pellet bubuk, pakan ikan hias, serta jentik nyamuk dengan frekuensi dua kali sehari. Untuk menjaga kualitas air di dalam akuarium tetap stabil, dilakukan penyiponan kotoran ikan selama masa pemeliharaan. Penyiponan sisa-sisa pakan dilakukan setiap hari disertai penggantian air sekitar 20-30\%. Pemeliharaan anak ikan gapi dilakukan hingga berumur 2-4 minggu.

\section{Identifikasi jenis kelamin ikan uji}

Identifikasi jenis kelamin anak ikan gapi dapat dilakukan setelah larva berumur 2-4 minggu. Pengamatan morfologis dilakukan dengan melihat ciri fisik anak ikan gapi. Ikan jantan dapat dikenali dengan memiliki warna yang lebih gelap, sirip yang lebih panjang dan jika diamati dari arah dorsal ukuran tubuh lebih kecil diban- dingkan dengan ikan betina dan khusus pada bagian sirip anal memiliki bentuk yang lancip atau meruncing membentuk gonopodium. Ikan betina dicirikan warna lebih pucat, dan sirip yang lebih pendek khusus pada bagian sirip anal memiliki bentuk yang agak bulat melengkung. Selain itu ikan jantan terlihat lebih agresif dibandingkan dengan ikan betina.

\section{Parameter penelitian}

Parameter yang diamati adalah proporsi jenis kelamin anak ikan gapi setelah diberikan ekstrak jeroan teripang pasir. Pengamatan terhadap jenis kelamin anak ikan gapi dilakukan secara morfologis dengan melihat ciri fisik ikan.

Persentase individu jantan dihitung dengan rumus :

Persentase jantan $=$ (jumlah jantan/jumlah total ikan) x $100 \%$

Tingkat sintasan dihitung dengan menggunakan rumus:

Tingkat sintasan $=($ jumlah ikan yang hidup/jumlah total ikan) x 100\%

\section{Analisis data}

Data dianalisis menggunakan analisis of varian (ANOVA) dan uji lanjut berupa Uji Tuckey untuk menentukan adanya hubungan antara dosis pada tiap perlakuan dengan jenis kelamin.

\section{Hasil}

Nisbah kelamin jantan

Berdasarkan hasil identifikasi pada akhir pengujian ekstrak jeroan teripang pasir terhadap ikan gapi dengan lama perendaman selama 24 jam dan masa pemeliharaan selama 2-4 minggu, didapatkan data rata-rata persentase jenis kelamin jantan untuk taraf perlakuan A (kontrol negatif), B, C, D, dan E (kontrol positif) berturut- 
turut yaitu $0,0 \% ; 50,00 \% ; 64,88 \% ; 88,89 \%$ dan $33,33 \%$.

Hasil analisis of varian dengan taraf kepercayaan $95 \%$ terbukti bahwa perlakuan memberikan pengaruh nyata terhadap nisbah kelamin. Hasil analisis menggunakan Uji Tuckey menunjukkan bahwa perlakuan B, C, D, dan E berbeda nyata dengan perlakuan A. Perlakuan B dan C tidak berbeda nyata dengan perlakuan E, namun perlakuan D berbeda nyata dengan perlakuan E. Hal tersebut menunjukkan bahwa ekstrak jeroan teripang pasir dan $17 \alpha$-metiltestosteron yang diberikan dapat mengarahkan terbentuknya kelamin jantan pada ikan gapi.

Peningkatan jumlah persentase ikan gapi yang berkelamin jantan dari hasil perendaman embrio dengan menggunakan ekstrak jeroan te- ripang memperlihatkan dosis terbaik pada perlakuan D (30 mg L ${ }^{-1}$ ) sebesar 88,89\%. jika dibandingkan dengan perlakuan A (Kontrol -) dan perlakuan E (Kontrol +), walaupun tidak berbeda nyata antar perlakuan B dan C (Gambar 1).

\section{Tingkat sintasan ikan gapi}

Tingkat sintasan ikan gapi selama pemeliharaan 2-4 minggu menggunakan dosis yang berbeda didapatkan data berkisar antara 43,7\%$86,9 \%$ (Gambar 2). Pada perlakuan dosis kontrol tingkat sintasannya sangat tinggi yakni $86,9 \%$ sangat jauh berbeda dengan perlakuan lain seperti perlakuan dengan metiltestosteron yang memiliki tingkat sintasan $53,57 \%$ serta perlakuan pemberian ekstrak jeroan teripang pasir yang berkisar an$\operatorname{tara} 43,7 \%-73,15 \%$.

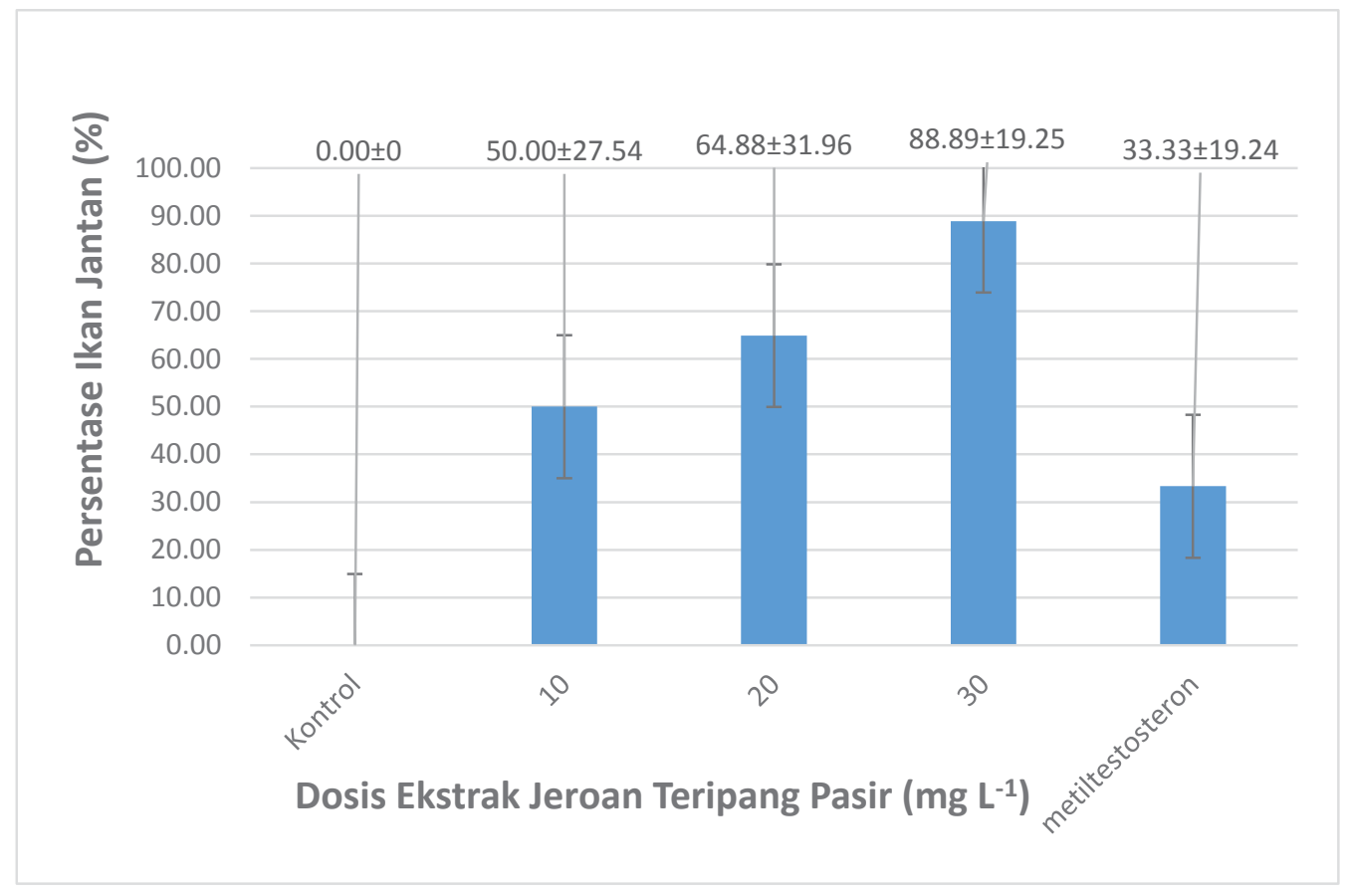

Gambar 1. Persentase ikan gapi jantan dengan pemberian ekstrak jeroan teripang pasir pada dosis yang berbeda dan direndam selama 24 jam. 


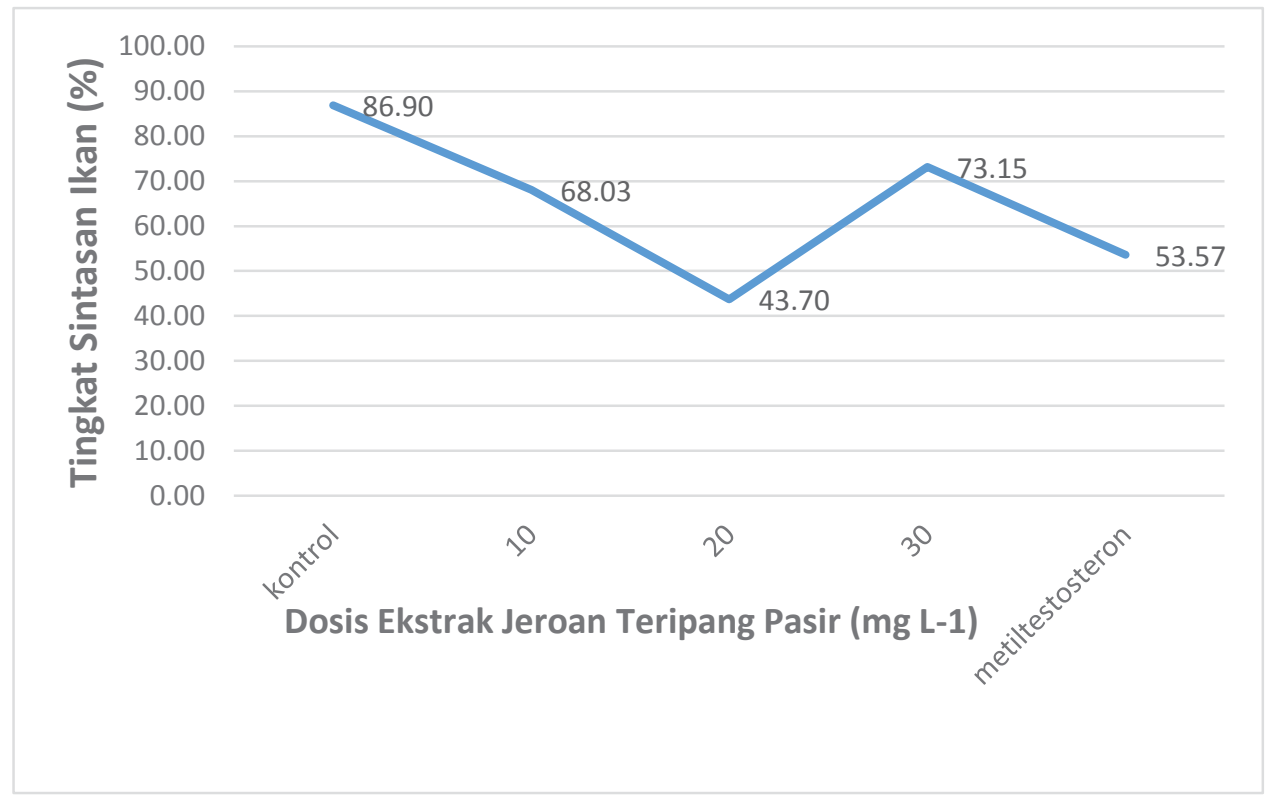

Gambar 2. Persentase tingkat sintasan ikan gapi dengan pemberian perlakuan dengan dosis yang berbeda

\section{Pembahasan}

\section{Nisbah kelamin jantan}

Berdasarkan hasil penelitian, tampaknya pembentukan kelamin jantan tertinggi terjadi pada perlakuan D dengan dosis perendaman $30 \mathrm{mg}$ $\mathrm{L}^{-1}$ yang direndam selama 24 jam yaitu $88,89 \%$. Ini membuktikan bahwa ekstrak jeroan teripang pasir dapat memberikan respons positif terhadap peningkatan persentase jantan pada ikan gapi. Triajie (2008) menyatakan bahwa ekstrak teripang pasir merupakan hormon androgenik yang dapat menyebabkan bertambahnya level testosteron dalam tubuh sehingga dapat mengarahkan jenis kelamin menjadi jantan. Konsentrasi testosteron dalam satu gram ekstrak steroid dari jeroan teripang sebesar 527 ppm (Emelda 2008) dan ini merupakan kandungan tertinggi jika dibandingkan dengan bagian tubuh lain dari teripang pasir (Kustiariyah 2006). Hasil yang sama juga diperoleh dalam penelitian Yustina et al. (2012) pada ikan cupang (Betta splendens) dengan menggunakan ekstrak steroid teripang $30 \mathrm{mg} \mathrm{L}^{-1}$ (perlakuan D) menghasilkan jantan hingga $66,66 \%$.
Diduga perendaman ekstrak steroid teripang dengan dosis $30 \mathrm{mg} \mathrm{L}^{-1}$ ini merupakan dosis yang optimum yang dapat memberikan hasil penjantanan maksimal pada ikan gapi dan ikan cupang. Sementara pada dosis $10 \mathrm{mg} \mathrm{L}^{-1}$ (perlakuan B) dan $20 \mathrm{mg} \mathrm{L}^{-1}$ (perlakuan $\mathrm{C}$ ) menunjukkan hasil yang lebih rendah disebabkan pada dosis tersebut belum mampu mengubah jenis kelamin ikan secara sempurna bahkan dapat mengakibatkan individu interseks (Muslim et al. 2011a). Penggunaan metiltestosteron juga menunjukkan persentase jantan yang jauh lebih rendah dibandingkan dengan perlakuan ekstrak jeroan teripang pasir. Hasil ini agak berbeda jika dibandingkan dengan hasil yang diperoleh Zairin et al. (2002) dan Arfah et al. (2005). Penelitian Zairin et al. (2002) memperoleh persentase keturunan jantan hingga $100 \%$ melalui perendaman metiltestosteron sintetis dengan dosis $2 \mathrm{mg} \mathrm{L}^{-1}$ selama 24 dan 48 jam, sementara penelitian Arfah et al. (2005) mendapatkan hasil persentase keturunan jantan tertinggi $92,67 \%$ dengan menggunakan dosis 1 mg $\mathrm{L}^{-1}$ yang dikombinasikan dengan perlakuan 
suhu $27^{\circ} \mathrm{C}$. Perbedaan dengan hasil penelitian kami diduga akibat tingginya dosis metiltestosteron yang diberikan yaitu $22 \mathrm{mg} \mathrm{L} \mathrm{L}^{-1}$. Penggunaan dosis metiltestosteron $22 \mathrm{mg} \mathrm{L}^{-1}$ didasari oleh penelitian yang dilakukan oleh Huwoyon et al. (2008) yang menggunakan dosis metiltestosteron 5-20 $\mathrm{mg} \mathrm{L}^{-1}$ menunjukkan persentase jan$\tan <90 \%$. Oleh karena rendahnya persentase jantan yang dihasilkan pada dosis $20 \mathrm{mg} \mathrm{L}^{-1}$, sehingga dalam penelitian ini kami menggunakan dosis $22 \mathrm{mg} \mathrm{L}^{-1}$. Selain itu dosis yang kami gunakan dalam penelitian ini sesuai dengan dosis yang digunakan oleh Yustina et al. (2012) dalam penelitiannya dengan menggunakan tepung teripang pasir pada ikan cupang. Pada kontrol negatif tidak dapat menghasilkan ikan jantan $(0 \%)$ dan ini menunjukkan bahwa pada kontrol tersebut tidak terdapat proses pembalikan kelamin dari betina ke jantan. Hal ini kemungkinan disebabkan adanya nisbah yang tidak seimbang antara jantan dan betina karena ditentukan oleh sifat genetik penentu jenis kelamin (Zairin et al. 2002). Dalam kasus ini penelitian ini menunjukkan bahwa sifat genetik penentu jenis kelamin pada betina lebih dominan dibandingkan dengan jantan.

Pemberian dosis hormon steroid harus tepat sehingga dapat menghambat pembentukan ovari dan mempercepat pembentukan gonad jantan, sehingga gonad akan berkembang menjadi testis (Yustina et al. 2012). Dosis hormon yang berlebihan dapat menyebabkan timbulnya tekanan saat pembentukan gonad, efek paradoksial dan tingginya mortalitas (Mardiana 2009). Selain faktor dosis, metode dan waktu pemberian hormon serta suhu juga merupakan faktor penting yang memengaruhi keberhasilan pembalikan kelamin (Purwati et al. 2004). Menurut Pandian \& Sheela (1995), perlakuan melalui oral dan perendaman untuk pembalikan kelamin merupakan metode yang terbaik dalam pemanfaatan hor- mon steroid. Dalam metode perendaman, masuknya hormon ke dalam tubuh larva diduga melalui proses osmosis. Dosis hormon dalam media pemeliharaan lebih tinggi daripada dosis hormon di dalam tubuh larva itu sendiri, sehingga hormon di dalam media masuk secara difusi ke dalam tubuh larva (Irmasari et al. 2012), kemudian lanjut ke peredaran darah dan mencapai target perlakuan akhir pada gonad (Akbar \& Hanafie 2013). Penyerapan hormon yang masuk ke dalam tubuh sangat dipengaruhi oleh dosis hormon dan waktu perendaman (Muslim 2010).

Keberhasilan pengarahan kelamin sangat dipengaruhi oleh waktu pemberian hormon steroid (Hidayani et al. 2016), karena berkaitan dengan diferensiasi yang bersifat khas pada setiap spesies (Riani et al. 2010). Menurut Mardiana (2009), umumnya pada ikan periode diferensiasi seks terjadi saat stadia larva hingga burayak, kecuali pada famili Poecilidae yang hanya terjadi pada fase embrio. Stadia larva merupakan periode labil ketika gonad belum terdiferensiasi (Riani et al. 2010), sehingga mudah dipengaruhi oleh hormon dari luar (Purwati et al. 2004). Hal tersebut disebabkan pada stadia ini perkembangan otak masih dalam keadaan bipotensial dalam pembentukan kelamin baik secara fenotip, tingkah laku maupun fungsional (Carman et al. 2008, Kautsari et al. 2015). Selain itu aplikasi pada fase ini juga akan memberikan efek perubahan yang bersifat permanen (organisational effect) (Arisandi 2012). Berdasarkan hasil penelitian sebelumnya, masa diferensiasi ikan gapi yaitu pada saat embriogenesis dan larva, bahkan hingga larva berumur 12 hari sehingga aplikasi pembalikan kelamin dilakukan sebelum embrio dilahirkan (Sarida et al. 2011).

Berbeda dengan ikan lainnya yang umumnya bersifat ovipar (menghasilkan telur), ikan gapi merupakan ikan yang bersifat ovovivipar 
yaitu ikan yang menghasilkan anak (Huwoyon et al. 2008). Pembuahan terjadi di dalam tubuh dan telur-telur tersebut akan menetas didalam tubuh induknya; selanjutnya embrio berkembang menjadi larva yang cukup besar dan kuat dilahirkan (Fahmi 2001). Makanan diperoleh embrio secara langsung dari kuning telur selama berada didalam perut induknya (Jollie \& Jollie 1964). Pola reproduksi inilah yang sangat memengaruhi keberhasilan pembalikan kelamin pada ikan gapi karena pemberian hormon dapat dilakukan melalui perendaman induk yang akan melahirkan dapat menghasilkan persentase anak jantan mencapai $100 \%$ (Huwoyon et al. 2008). Hasil penelitian ini menunjukkan persentase kurang dari 90\% namun telah menunjukkan perbedaan yang nyata jika dibandingkan dengan perlakuan kontrol. Pada Gambar 1 tampak perlakuan kontrol hanya menghasilkan anakan betina 100\%. Diduga hal ini sangat terkait dengan perubahan suhu yang terjadi ketika penelitian dilakukan.

Suhu merupakan salah satu faktor lingkungan yang sangat berpengaruh terhadap penentuan jenis kelamin pada reptil dan beberapa ikan (Budd et al. 2015). Pada ikan gapi, jumlah ikan jantan akan meningkat seiring dengan peningkatan suhu dan jika terjadi penurunan suhu maka jumlah ikan betina lebih banyak (Karayücel et al. 2006). Hasil penelitian Arfah et al. (2005) menunjukkan proporsi induk jantan yang lebih tinggi pada induk yang diinkubasi pada suhu $30^{\circ} \mathrm{C}$ dibandingkan pada suhu $27^{\circ} \mathrm{C}$. Mulyasih et al. (2012) juga memperoleh hasil persentase ikan gapi jantan yang tinggi ketika diinkubasi pada suhu $32^{\circ} \mathrm{C}$ yang dikombinasikan dengan dosis madu propolis $25 \mu \mathrm{l} / 1$ sebesar $68,72 \%$. Hal ini diduga karena suhu yang tinggi dapat meningkatkan kinerja hormon testosteron dan ketotestosteron. Selain itu dengan suhu yang tinggi, memungkinkan adanya faktor lain yang me- mengaruhi kemampuan sperma Y dalam membuahi telur lebih tinggi daripada sperma X, sehingga sintasan ikan jantan lebih baik dibandingkan dengan ikan betina (Arfah et al. 2005). Oleh karena itu perlakuan hormon serta peningkatan suhu dapat meningkatkan proporsi jantan yang lebih tinggi.

\section{Tingkat sintasan}

Selama masa pemeliharaan tingkat sintasan ikan gapi cenderung rendah. Hal ini diduga akibat adanya serangan penyakit/parasit yang mengakibatkan kematian massal pada sebagian besar larva yang dipelihara meskipun telah dilakukan upaya pencegahan mikroorganisme melalui sterilisasi media dan peralatan. Selain itu kemungkinan disebabkan penyiponan yang mengakibatkan larva stres. Masa larva merupakan masa yang sangat rentan terhadap kematian karena belum mampu beradaptasi dengan lingkungan (Muslim et al. 2011b). Akibatnya jika membandingkan antara tingkat sintasan larva pada perlakuan yang diberi ekstrak jeroan teripang dengan perlakuan dosis $0 \mathrm{mg} \mathrm{L}^{-1}$ (kontrol) serta metiltestosteron terjadi perbedaan yang sangat signifikan. Pada perlakuan dosis $0 \mathrm{mg} \mathrm{L^{-1 }}$ (kontrol) tingkat sintasannya sangat tinggi yakni 86,9\% sangat jauh berbeda dengan perlakuan lain seperti perlakuan dengan metiltestosteron yang memiliki tingkat sintasan $53.57 \%$ serta perlakuan pemberian ekstrak jeroan teripang pasir yang berkisar antara 43.7\%-68.03\%. Perbedaan ini kemungkinan disebabkan adanya pengaruh alkohol dari hasil perendaman induk yang memengaruhi ke keturunan ikan gapi. Alkohol bersifat toksik walaupun dalam jumlah sedikit jika digunakan dalam perendaman dalam waktu yang cukup lama (Hakim 2008).

Dari data yang dihasilkan dapat dilihat bahwa tingkat sintasan larva ikan gapi pada per- 
lakuan ekstrak jeroan teripang dikategorikan baik jika dibandingkan dengan kontrol perlakuan metiltestosteron walaupun dapat dilihat bahwa pada perlakuan $\mathrm{C}$ pemberian ekstrak tepung teripang merupakan tingkat sintasan terendah yakni sebesar 43,7\%. Namun untuk perlakuan B dan D ekstrak jeroan teripang sangat jauh lebih baik di kisaran 68,03\% dan 73,15\% apabila dibanding perlakuan metiltestosteron yang tingkat sintasan benih ikannya hanya 53,57\%. Hal ini diduga karena adanya kandungan bahan lain yang terdapat dalam tubuh teripang. Tepung teripang dalam 100 gram mengandung berbagai macam asam amino esensial dan non esensial serta mengandung asam lemak jenuh dan tak jenuh. Beberapa asam amino sangat berguna dalam peningkatan libido maupun pembentukan spermatozoa. Selain itu teripang juga mengandung hormon androgen yang memiliki sifat anabolik dalam merangsang pertumbuhan serta bertanggung jawab terhadap penampakan karakter dan fungsi kelamin jantan (Yustina et al. 2012). Penyebab dari rendahnya tingkat sintasan ikan pada perlakuan ekstrak jeroan teripang $20 \mathrm{mg} \mathrm{L}^{-1}$ akibat pada saat perendaman alkohol yang digunakan tidak teroksidasi dengan baik sehingga memengaruhi proses difusi hormon pada benih ikan nila dan menyebabkan ikan tersebut stres.

Tingkat sintasan antara perlakuan dengan pemberian ekstrak jeroan teripang dengan hormon $17 \alpha$-metiltestosteron tidak berbeda nyata. Ini menunjukkan bahwa penggunaan ekstrak jeroan teripang pasir dapat digunakan sebagai pengganti hormon $17 \alpha$-metiltestosteron karena penggunaan hormon ini lebih beresiko dibandingkan dengan penggunaan hormone steroid alami (Emilda 2015). Penggunaan hormon ini walaupun dalam dosis yang rendah namun dalam waktu yang lama menimbulkan berbagai macam dampak negative, salah satunya adalah menye- babkan pencemaran lingkungan dan kanker pada manusia (Sudrajat \& Saridah, 2006) serta kerusakan hati pada hewan uji (Yustina et al. 2012). Residu anabolic dari hormone $17 \alpha$-metiltestosteron sulit terdegradasi sehingga berpengaruh selain pada lingkungan juga pada ikan (Pandian \& Kirankumar 2003). Oleh karena itu DKP (2008) memasukkan hormon ini sebagai salah satu obatobatan terlarang yang dilarang penggunaannya dalam kegiatan budi daya perikanan.

\section{Simpulan}

Ekstrak jeroan teripang yang diberikan pada larva uji melalui metode perendaman, efektif untuk pembalikan kelamin ikan gapi. Ekstrak jeroang teripang dengan dosis $30 \mathrm{mg} \mathrm{L}^{-1}$ yang diberikan selama 24 jam mampu menghasilkan ikan jantan tertinggi hingga 88,89\%.

\section{Persantunan}

Penulis mengucapkan terima kasih kepada Kemenristekdikti yang telah mendanai penelitian ini melalui kegiatan Program Kreativitas Mahasiswa Penelitian Tahun 2017.

\section{Daftar pustaka}

Akbar J, Hanafie A. 2013. Efektivitas non steroid akriflavin pada pembalikan kelamin jantan ikan baung (Hemibagrus nemurus) dengan dosis dan lama perendaman berbeda sebagai upaya untuk mengatasi kelangkaan induk jantan. In: Prodi Pengelolaan Sumber daya Alam dan Lingkungan, PPs Unlam. Prosiding Seminar Nasional 2013. Menuju Pengelolaan Sumber Daya Alam dan Lingkungan yang Berkelanjutan. Universitas Lambung Mangkurat Press 2013. Banjarmasin. Hlm. 106-113.

Arfah H, Kadriah IAK, Carman O. 2005. Efek manipulasi hormon $17 \alpha$-metiltestosteron pada berbagai variasi temperatur air terhadap rasio kelamin ikan gapi (Poecilia reticulata Peters). Jurnal Akuakultur Indonesia 4(1): 37-40.

Arisandi, A. 2012. Efektivitas dan efek toksik ekstrak steroid teripang dan $7 \alpha$-metiltes- 
tosteron pada manipulasi kelamin udang galah. Jurnal Kelautan 5(2): 108-116.

Budd AM, Banh QQ, Domingos JA, Jerry DR. 2015. Sex control in fish: Approaches, challenges and opportunities for aquaculture. Journal of Marine Science and Engineering, 3(2): 329-355.

Carman O, Jamal MY, Alimuddin. 2008. Oral administration of $17 \alpha$-Methyltestosterone increased male percentage of freshwater crayfish Cherax quadricarinatus. Jurnal Akuakultur Indonesia, 7(1): 25-32.

DKP. 2008. 21 Obat-obatan yang dilarang. Dirjen Perikanan Budidaya, Balai Besar Pengembangan Budidaya Air Tawar. Sukabumi.

Emelda. 2008. Pemanfaatan steroid asal jeroan teripang sebagai bahan aktif dalam sex reversal pada ikan gapi. Tesis. Institut Pertanian Bogor. Bogor. 58 hlm.

Emilda E. 2015. Pemanfaatan ekstrak steroid asal jeroan teripang untuk sex reversal pada ikan gapi. Faktor Exacta, 5(4): 336-349.

Fahmi. 2001. Tingkah laku reproduksi pada ikan. Oseana, 26(1): 17-24.

Gemilang BRI, Basuki F, Yuniarti T. 2016. Pengaruh lama waktu pemberian tepung testis sapi terhadap keberhasilan menghasilkan jantan ikan cupang (Betta sp.). Journal of Aquaculture Management and Technology, 5(1): 124-129.

Hakim RR. 2008. Optimalisasi pemberian dosis hormon metiltestosteron terhadap keberhasilan pembentukan monoseks jantan lobster air tawar (Cherax quadricarinatus). Jurnal Protein Fakultas Peternakan dan Perikanan UMM. 15(1): 1-17.

Haq HK, Santika A, Herawati T. 2013. Pengaruh lama waktu perendaman induk dalam larutan madu terhadap pengalihan kelamin anak ikan Gapi (Poecilia reticulata). Jurnal Perikanan dan Kelautan, 4(3): 117125.

Hidayani AA, Fujaya Y, Trijuno DD, Aslamyah S. 2016. Pemanfaatan tepung testis sapi sebagai hormon alami pada penjantanan ikan cupang, Betta spelendens Regan, 1910. Jurnal Iktiologi Indonesia, 16(1): 91-101.

Hunter GA, Donaldson EM. 1983. Hormonal sex control and it's application to fish culture. In: Hoar WS, Randall DJ, Donaldson EM.
(Eds.). Fish Physiology. Vol. 9 Reproduction, Part B Behaviour and Fertility Control. Academic Press. New York. pp. 223 291.

Huwoyon GH, Rustidja G, Rudhy. 2008. Pengaruh pemberian hormone methyltestosterone pada larva guppy (Poecilia reticulata) terhadap perubahan jenis kelamin. Jurnal Zoo Indonesia, 17(2): 49-54.

Irmasari, Iskandar, Subhan U. 2012. Pengaruh ekstrak tepung testis sapi dengan konsentrasi yang berbeda terhadap keberhasilan maskulinisasi ikan nila merah. Jurnal Perikanan dan Kelautan, 3(4): 115-121.

Jollie WP, Jollie LG 1964. The fine structure of the ovarian follicle of the ovoviviparrous poecillid fish. Lebistes reticulates. I. Maturation of follicular epithelium. Journal of Morphology, 144(3): 479-502.

Karayücel I, Ak O, Karayücel S. 2006. Effect of temperature on sex ratio in Guppy Poecilia reticulata (Peters, 1860). Aquaculture Research, 37(2): 139-150.

Karnila R, Astawan M, Sukarno, Wresdiyati T. 2011. Karakteristik konsentrat protein teripang pasir (Holothuria scabra J.) dengan bahan pengestrak aseton. Jurnal Perikanan dan Kelautan, 16(1): 90-102.

Kautsari N, Rahma S, Syafikri, D. 2015. Pengaruh perendaman larva dengan berbagai dosis madu Sumbawa terhadap nisbah jenis kelamin dan pertumbuhan ikan nila, Oreochromis niloticus (Linnaeus, 1758). Jurnal Iktiologi Indonesia, 15(2): 99-106.

Kustiariyah. 2006. Isolasi dan uji aktivitas biologis senyawa steroid dari teripang sebagai aprosidiaka alami. Tesis. Sekolah Pascasarjana. Institut Pertanian Bogor. Bogor. $79 \mathrm{hlm}$.

Mantau Z. 2005. Produksi benih ikan nila jantan dengan rangsangan hormon metil testosteron dalam tepung pelet. Jurnal Litbang Pertanian, 24(2): 80-84.

Mardiana. 2009. Teknologi pengarahan kelamin ikan menggunakan madu. Jurnal PENA Akuatika, 1(1): 37-43.

Mulyasih D, Tarsim, Sarida M. 2012. Penggunaan suhu dan propolis yang berbeda terhadap nisbah kelamin ikan guppy (Poecilia reticulata). Jurnal Rekayasa dan Teknologi Budidaya Perairan, 1(1): 25-30. 
Muslim, Zairin M Jr, Utomo NBP. 2011a. Maskulinisasi ikan nila (Oreochromis niloticus) dengan pemberian tepung testis sapi. Jurnal Akuakultur Indonesia, 10(1): 51-58

Muslim, Helmizuryani, Nopirman. 2011b. Pengaruh hormon testosteron terhadap maskulinisasi benih ikan nila (Oreochromis niloticus) dengan metode dipping. Majalah Ilmiah Sriwijaya, 19(12): 717-724.

Muslim. 2010. Peningkatan persentase ikan guppy (Poecilia reticulata) jantan dengan perendaman induk bunting dalam larutan hormon 17 $\alpha$-Metiltestosteron. Jurnal Klorofil, 5(2): 61-66.

Muslim, 2011. Maskulinisasi ikan nila (Oreochromis niloticus) dengan pemberian tepung testis sapi. Jurnal Akuakultur Indonesia, 10(1): 51-58.

Pandian TJ, Kirankumar. 2003. Recent advances in hormonal induction of sex reversal in fish. Journal of Applied Aquaculture Food, 13(3/4) : 205-230.

Pandian TJ, Sheela SG. 1995. Hormonal inductiore of sex reversal in fish. Aquaculture, 138 (1-4): 1-22.

Phelps RP, Sanchez WC, Couturier GM, Abiado M, Dabrowski, K. 2001. Studies on fate of methyltestosteron and its metabolism in tilapia and on the use of phytochemicals as an alternative method to produce a monosex population of tilapia. Twenty-First Annual Technical Report. Aquaculture CRSP, Oregon State University, Cprvallis, Oregon. pp. 53-60.

Piferrer F. 2001. Endocrine sex control strategies for the feminization of teleost fish. Aquaculture, 197(1-4): 229-281.

Purwati S, Carman O, Zairin Jr M. 2004. Feminisasi ikan betta (Betta Splendens Regan) melalui perendaman embrio dalam larutan hormon estradiol-17 $\beta$ dengan dosis 400 $\mu \mathrm{g} / \mathrm{L}$ selama 6,12,18 dan 24 Jam. Jurnal Akuakultur Indonesia, 3(3): 9-13.

Riani E, Sudrajat AO, Triajie H. 2010. Efektivitas ekstrak teripang pasir yang telah difor- mulasikan terhadap maskulinisasi udang galah. Bionatura-Jurnal Ilmu-ilmu Hayati dan Fisik, 12(3): 142-152.

Sarida M, Putra DD, Marsewi HSY. (2011). Produksi monoseks guppy (Poecilia reticulata) jantan dengan perendaman induk bunting dan larva dalam propolis berbagai aras dosis. Zoo Indonesia, 20(2): 1-10.

Sudrajat AO, Sarida M. 2006. Efektivitas pemberian aromatase inhibitor dan $17 \alpha$-metiltestosteron melalui pakan dalam produksi udang Galah (Macrobrachium rosenbergii de Man) jantan. Aquacultura Indonesiana, 7(1): 71-76.

Triajie H. 2008. Efektivitas ekstrak teripang pasir yang telah diformulasikan terhadap maskulinisasi udang galah. Tesis. Institut Pertanian Bogor. Bogor. $76 \mathrm{hlm}$.

Triajie H. 2010. Uji aktivitas ekstrak teripang pasir yang telah diformulasikan terhadap kemampuan sex reversal dan sintasan udang galah (Macrobrachium rosenbergii). Jurnal Kelautan: Indonesian Journal of Marine Science and Technology, 3(1): 4147.

Yuniarti T, Hanif S, Prayoga T, Suroso S. 2009. Teknik produksi induk betina ikan nila (Oreochromis niloticus) tahap verifikasi jantan fungsional (XX). Jurnal Saintek Perikanan, 5(1): 38-43.

Yustina, Arnetis D, Ariani. 2012. Efektivitas tepung teripang pasir (Holothuria scabra) terhadap maskulinisasi ikan cupang (Betta splendens). Jurnal Biogenesis, 9(1): 67-73

Zairin Jr M, Yunianti A, Dewi RRSPS, Sumantadinata K. 2002. Pengaruh lama waktu perendaman induk di dalam larutan hormon $17 \alpha$-Metiltestosteron terhadap nisbah kelamin anak ikan gapi, Poecilia reticulata Peters. Jurnal Akuakultur Indonesia, 1(1): 31-35.

Zairin Jr M. 2002. Sex Reversal Memproduksi Benih Ikan Jantan atau Betina. Penebar Swadaya. Jakarta. $113 \mathrm{hlm}$. 